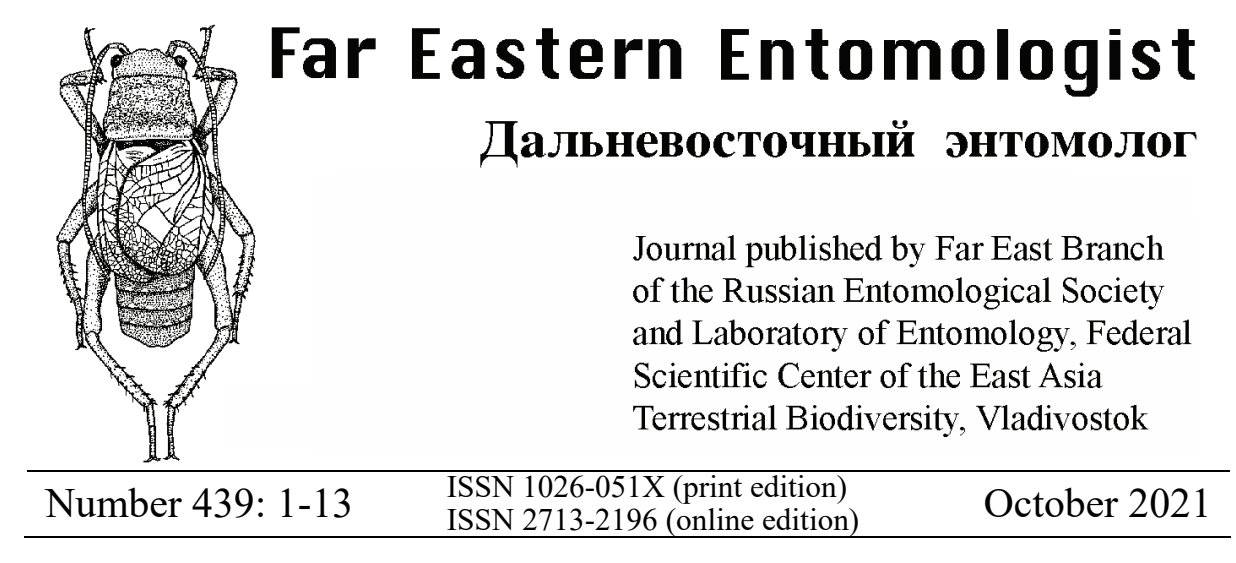

https://doi.org/10.25221/fee.439.1

http://zoobank.org/References/278A111E-62AA-4340-B035-9733B6CA7EDE

\title{
A NEW GENUS OF THE TRIBE OSMINIINI (LEPIDOPTERA: SESIIDAE) FROM THE ORIENTAL REGION
}

\section{O. G. Gorbunov}

A.N. Severtsov Institute of Ecology and Evolution, Russian Academy of Sciences, Leninsky prospekt 33, Moscow, 119071,Russia.E-mail: gorbunov.oleg@mail.ru

Summary. The genus Pyrophleps Arita et O. Gorbunov, 2000, stat. resurr. is restored from synonyms of the genus Aschistophleps Hampson, 1893. A new genus Nepyrophleps gen. n. is described. This new genus consists of three species: $N$. haematochrodes (Le Cerf, 1912), comb. n. (type species), N. cucphuonganae (Arita et O. Gorbunov, 2000), comb. n., and N. bicella (Xu et Arita, 2015), comb. n. A detailed redescription of $A$. haematochrodes is presented, including the male genitalia. This species is reported for Laos for the first time.

Key words: clearwing moths, taxonomy, Pyrophleps, Nepyrophleps, Laos, South-East Asia.

А О. Г. Горбунов. Новый род трибы Osminiini (Lepidoptera: Sesiidae) из Ориентальной области // Дальневосточный энтомолог. 2021. N 439. С. 1-13.

Резюме. Род Pyrophleps Arita et O. Gorbunov, 2000, stat. resurr. восстановлен из синонимов рода Aschistophleps Hampson, 1893. Описан новый род Nepyrophleps gen. n. В этот род включены три вида: N. haematochrodes (Le Cerf, 1912), comb. n. (типовой вид), N. сисphuonganae (Arita et O. Gorbunov, 2000), comb. n., и N. bicella (Xu et Arita, 2015), comb. n. Приведено детальное переописание $A$. haematochrodes, включая гениталии самца. Этот вид впервые приводится для Лаоса. 


\section{INTRODUCTION}

There are only a few publications on the clearwing moths tribe Osmiini (Lepidoptera: Seciidae) fauna of South-East Asia and South China (Gorbunov \& Arita, 1995; Arita \& Gorbunov, 2000; Xu et al., 2015; Gorbunov, 2015; Skowron Volponi \& Volponi, 2017; Kallies \& Stolc, 2018). Therefore the taxonomic status and composition of some genera are unclear. The genus Pyrophleps Arita et O. Gorbunov, 2000 was established for P. nigripennis Arita et O. Gorbunov, 2000 as the type species and consists of six species (Arita \& Gorbunov, 2000). Recently this genus was synonymized with Aschistophleps Hampson, 1893.

In this article Pyrophleps is considered as a distinct genus, the redescription of Aschistophleps haematochrodes Le Cerf, 1912 is given and the new genus is established. This is my second report dealing with results of an expedition to Laos in 2005 (Gorbunov, 2015).

\section{MATERIAL AND METHODS}

To redescribe $A$. haematochrodes, I took the specimen that superficially most resembles the holotype. It is described using a Leica EZ4 stereomicroscope with LED illuminations, and images are taken with a Sony ${ }^{\circledR} \alpha 450$ DSLR camera equipped with a Minolta ${ }^{\circledR} 50 \mathrm{f} / 2.8$ Macro lens. The figures of heads and hind leg tufts are taken with a Keyence ${ }^{\circledR}$ VHX-1000 Digital Microscope. The genitalia figures are taken with a Keyence ${ }^{\circledR}$ BZ-9000 Biorevo Fluorescence Microscope. The processing of all illustrations is finalized with the Adobe ${ }^{\circledR}$ Photoshop ${ }^{\circledR}$ CC 2020 software.

All pictures of the imagines are labeled with a number, consisting of letters and digits: name of the family, two consecutive digits separated by n-dash and a year following m-dash (e.g. SESIIDAE pictures No 0171-0172-2021). These letter and digit codes correspond to the numbering system of the figured specimens in the author's archive. The genitalia preparation is stored in a microtube with glycerol and pinned under the specimen. The dissected genitalia are equipped with the corresponding number placed in the microtube. This number as a label (e. g. Genitalia preparation No OG-064-2018) is pinned under the specimen and is listed in the archives of the author.

The names of plants are given in accordance with The Plant List (2013). The material studied is kept in the collection of the A.N. Severtsov Institute of Ecology and Evolution of the Russian Academy of Sciences, Moscow, Russia (COGM).

\section{TAXONOMY}

\section{Genus Pyrophleps Arita et O. Gorbunov, 2000, stat. resurr.}

Pyrophleps Arita et O. Gorbunov, 2000: 64. Synomymized under Aschistophleps Hampson, 1893 by Kallies \& Štolc (2018).

Type species: Pyrophleps nigripennis Arita et O. Gorbunov, 2000. 
REMARKS. In 2000, together with Yutaka Arita, I published a paper describing new taxa of clearwing moths of the tribe Osminiini of the Vietnamese fauna (Arita $\&$ Gorbunov, 2000), where the genus Pyrophleps was established as a new one. We included six species in that genus, of which three were described as new to science. We chose P. nigripennis Arita et O. Gorbunov, 2000 as the type species of the genus. We had no doubts that the second described species, $P$. vitripennis Arita et O. Gorbunov, 2000, is morphologically very close to the type species and there is no doubt that these two species form a separate natural taxon of the generic level. We had serious doubts about the inclusion of another new species in this genus: $P$. cucphuonganae Arita et O. Gorbunov, 2000, and along with it and the superficially very close Adixoa cruentata Swinhoe, 1896 and Aschistophleps haematochrodes Le

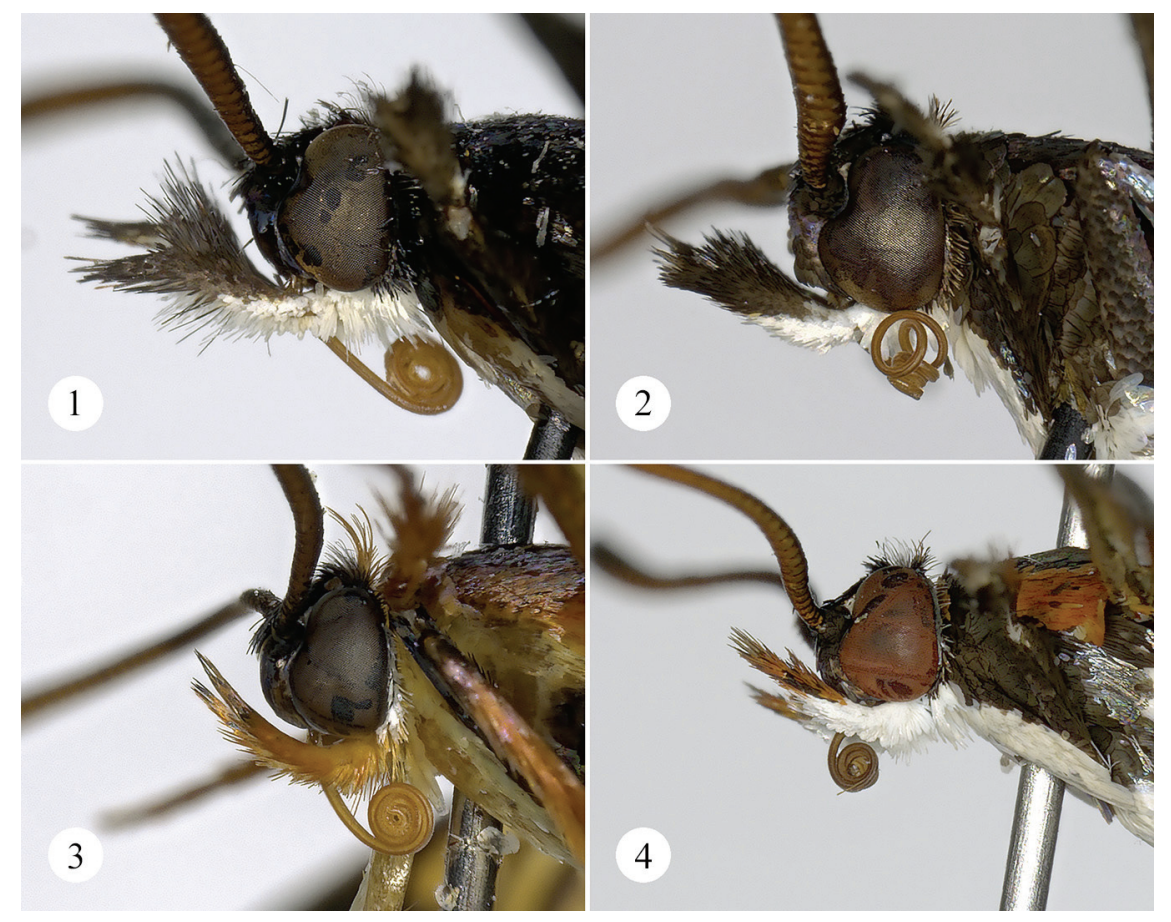

Figs 1-4. Labial palpus of Osminiini. 1 - Pyrophleps nigripennis Arita et O. Gorbunov, 2000. Paratype. Vietnam, Ninh Binh Province, Gia Vien, Cuc Phuong, 250 m, 24.IV.1998, Y. Arita leg. Sesiidae picture No 0115-0116-2021; 2 - Pyrophleps vitripennis Arita et O. Gorbunov, 2000. Paratype. Vietnam, Ninh Binh Province, Gia Vien, Cuc Phuong, $250 \mathrm{~m}$, 24.IV.1998, Y. Arita leg. Sesiidae picture No 0121-0122-2021; 3 - Aschistophleps longipoda Arita et O. Gorbunov, 2000. Laos, Khammouang Province, Ban Khounkham (Nahin), $18^{\circ} 13^{\prime} \mathrm{N}, 104^{\circ} 31^{\prime} \mathrm{E}, 200 \mathrm{~m}, 16 . I V .2005$, O. Gorbunov leg. Sesiidae picture No 0069-00702021; 4 - Nepyrophleps haematochrodes (Le Cerf, 1912), comb. n. Laos, Khammouang Province, Ban Khounkham (Nahin), 18 $13^{\prime}$ N, 104 $31^{\prime} \mathrm{E}, 200$ m, 25.IV.2005, O. Gorbunov leg. Sesiidae picture No 0171-0172-2021. 
Cerf, 1912. Unfortunately, at that time we had only a single specimen (holotype) of $P$. cucphuonganae, a photograph of the type $A$. cruentata, and a drawing of the type A. haematochrodes (Le Cerf, 1912: 54, fig. 1). The rather similar genitalia of $P$. cucphuonganae, $P$. nigripennis and $P$. vitripennis led us to believe that all these species should be placed in a single genus. Unfortunately, at that time we did not focus on and did not highlight in the figure (Arita \& Gorbunov, 2000: fig. 17b) a very important diagnostic feature, namely a row of strong, but light-coloured setae on the sacculus (Fig. 21). Beside this, we did not compare the shape of eyes and labial palpus $P$. nigripennis and $P$. cucphuonganae. Now I am confident that they can be used as diagnostic features.

Recently Kallies and Stolc (2018) synonymized the genus Pyrophleps Arita et O. Gorbunov, 2000 with the genus Aschistophleps Hampson, 1893. They wrote, "These species (they mean Pyrophleps spp. - my comment) were separated from Aschistophleps based on differences in the male genitalia and the constitution of the

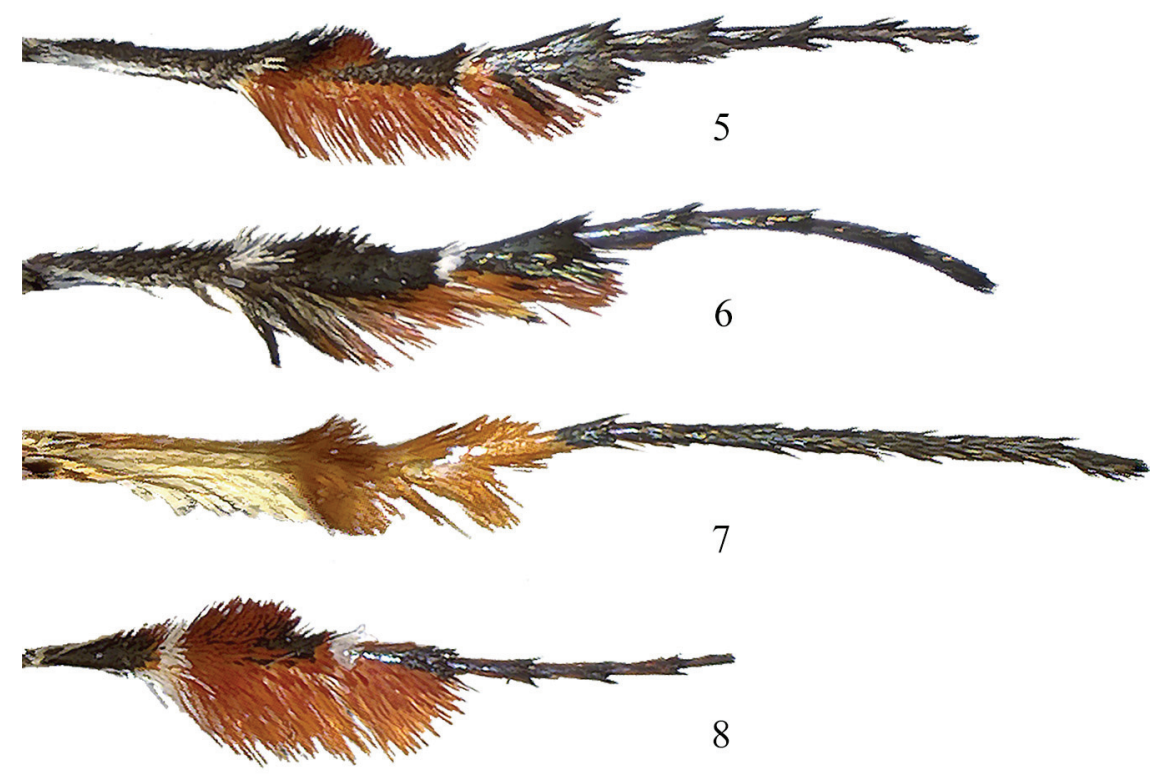

Figs 5-8. Hind leg tuft of Osminiini. 5 - Pyrophleps nigripennis Arita et O. Gorbunov, 2000. Sesiidae picture No 0113-0114-2021; 6 - Pyrophleps vitripennis Arita et O. Gorbunov, 2000. Paratype. Vietnam, Ninh Binh Province, Gia Vien, Cuc Phuong, 250 m, 24.IV.1998, Y. Arita leg. Sesiidae picture No 0121-0122-2021; 7 - Aschistophleps longipoda Arita et O. Gorbunov, 2000. Laos, Khammouang Province, Ban Khounkham (Nahin), $18^{\circ} 13^{\prime} \mathrm{N}, 104^{\circ} 31^{\prime} \mathrm{E}$, 200 m, 16.IV.2005, O. Gorbunov leg. Sesiidae picture No 0069-0070-2021; 8 - Nepyrophleps haematochrodes (Le Cerf, 1912), comb. n. Laos, Khammouang Province, Ban Khounkham (Nahin), 18 $13^{\circ} \mathrm{N}, 104^{\circ} 31^{\prime} \mathrm{E}, 200 \mathrm{~m}, 25 . \mathrm{IV} .2005$, O. Gorbunov leg. Sesiidae picture No 01710172-2021. 
hind leg scales. The new species (Aschistophleps ignisquamulata Kallies et Štolc, 2018 - my addition) from Thailand and Laos, however, does not fit the narrow definitions of either genus and displays a series of characteristics that show that this group of Osminiini is morphologically more diverse than previously anticipated." (Kallies \& Štolc, 2018: 596). I fully agree that "that group of Osminiini is morphologically more diverse than previously anticipated" (loc. cit.), but I am also sure that Aschistophleps ignisquamulata does not belong to either Aschistophleps or Pyrophleps. This is very clearly seen in the structure of the male genitalia (op. cit.: fig. 3). The generic position of this and some other species, which were previously included in the genus Pyrophleps, will be discussed in a forthcoming publication.

A detailed study of the abundant material collected in Laos in 2005 revealed several very interesting finds. One such interesting find is a fairly numerous series (67 males) of completely unexplored species Aschistophleps haematochrodes, which was included in the genus Pyrophleps only by its external similarity with $P$. cucphuonganae (see above). The study of the details of the external morphology and the genitalia made it possible to establish that these two species are indeed closely related. Moreover, the features of the morphology of these two species make it possible to distinguish them into a separate genus, and to restore the genus Pyrophleps from a synonym of Aschistophleps.

COMPOSITION. I currently include the following three species in this genus: P. nigripennis Arita et O. Gorbunov, 2000, P. vitripennis O. Gorbunov, 2000, and P. ellawi Skowron Volponi, 2017.

Genus Nepyrophleps O. Gorbunov, gen. $n$.

http://zoobank.org/NomenclaturalActs/082E9DDE-0824-4ED2-BC9B-E1E71E8D71B3

Type species: Aschistophleps haematochrodes Le Cerf, 1912.

DESCRIPTION. Male. Brightly-coloured, small-sized, long-legged clearwing moths with alar expanse 13-16 mm. Superficially resembling the genus Aschistophleps Hampson, 1893.

Head with antenna strongly clavate, without cilia in male; frons smooth-scaled; labial palpus (Fig. 4) long, somewhat turned-up, with a few hair-like scales distally; proboscis well-developed, long, functional; vertex covered with short hair-like scales. Thorax smooth-scaled, both metepimeron and metameron with long hairlike scales posteriorly. Hind leg with distal half of tibia and basal tarsomere tufted with long hair-like scales (Fig. 8). Abdomen smooth-scaled, anal tuft nearly undeveloped. Forewing with transparent areas rather well-developed; radial veins only four (I believe that vein $R_{3}$ and $R_{4}$ completely merged into a single vein $R_{3+4}$ ), veins $R_{1}$ and $R_{2}$ parallel, veins $R_{3+4}$ and $R_{5}$ separate basally; distance between base of veins $R_{5}$, and $M_{1}$, about half that between veins $R_{3+4}$ and $R_{5}$, distance between base of veins $M_{1}$ and $M_{2}$ about twice that between veins $M_{2}$ and $M_{3}$. Hindwing transparent or partially opaque; vein $\mathrm{M}_{3}$ arises from vein $\mathrm{CuA}_{1}$ slightly basal to cross-vein.

Male genitalia (Figs 21, 22). Uncus with a semi-oval plate of long hair-like setae lateral-apically, covering tuba analis like a collar; gnathos narrow, long, distinctly protruding caudally; valva gradually widens towards the center, and then narrows 


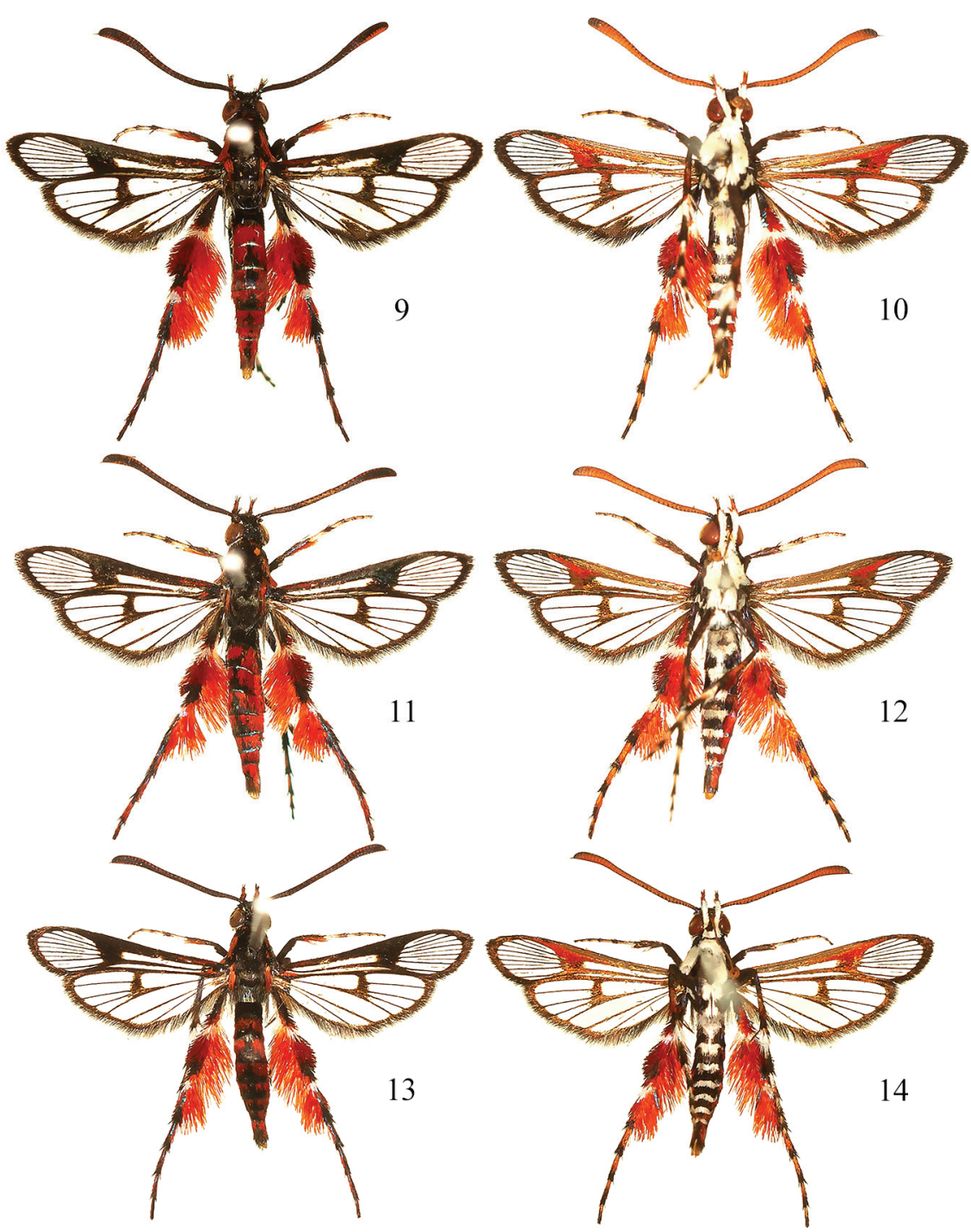

Figs 9-14. Variability of males of Nepyrophleps haematochrodes (Le Cerf, 1912), comb. n. 9 - upside. Laos, Khammouang Province, Ban Khounkham (Nahin), $18^{\circ} 13^{\prime} \mathrm{N}, 104^{\circ} 31^{\prime} \mathrm{E}$, 200 m, 25.IV.2005, O. Gorbunov leg. Sesiidae picture No 0171-2021. Alar expanse 14.4 $\mathrm{mm} ; 10$ - ditto underside. Sesiidae picture No 0172-2021; 11 - upside. Laos, Khammouang Province, Ban Khounkham (Nahin), 18 $13^{\circ}$ N, 104 $31^{\prime} \mathrm{E}, 200$ m, 28.IV.2005, O. Gorbunov leg. Sesiidae picture No 0151-2021. Alar expanse $14.0 \mathrm{~mm} ; 12$ - ditto underside. Sesiidae picture No 0152-2021; 13 - upside. Laos, Khammouang Province, Ban Khounkham (Nahin), $18^{\circ} 13^{\prime} \mathrm{N}, 104^{\circ} 31^{\prime} \mathrm{E}, 200 \mathrm{~m}, 28 . I V .2005$, O. Gorbunov leg. Sesiidae picture No 0157-2021. Alar expanse $13.5 \mathrm{~mm} ; 14$ - ditto underside. Sesiidae picture No 0158-2021. 

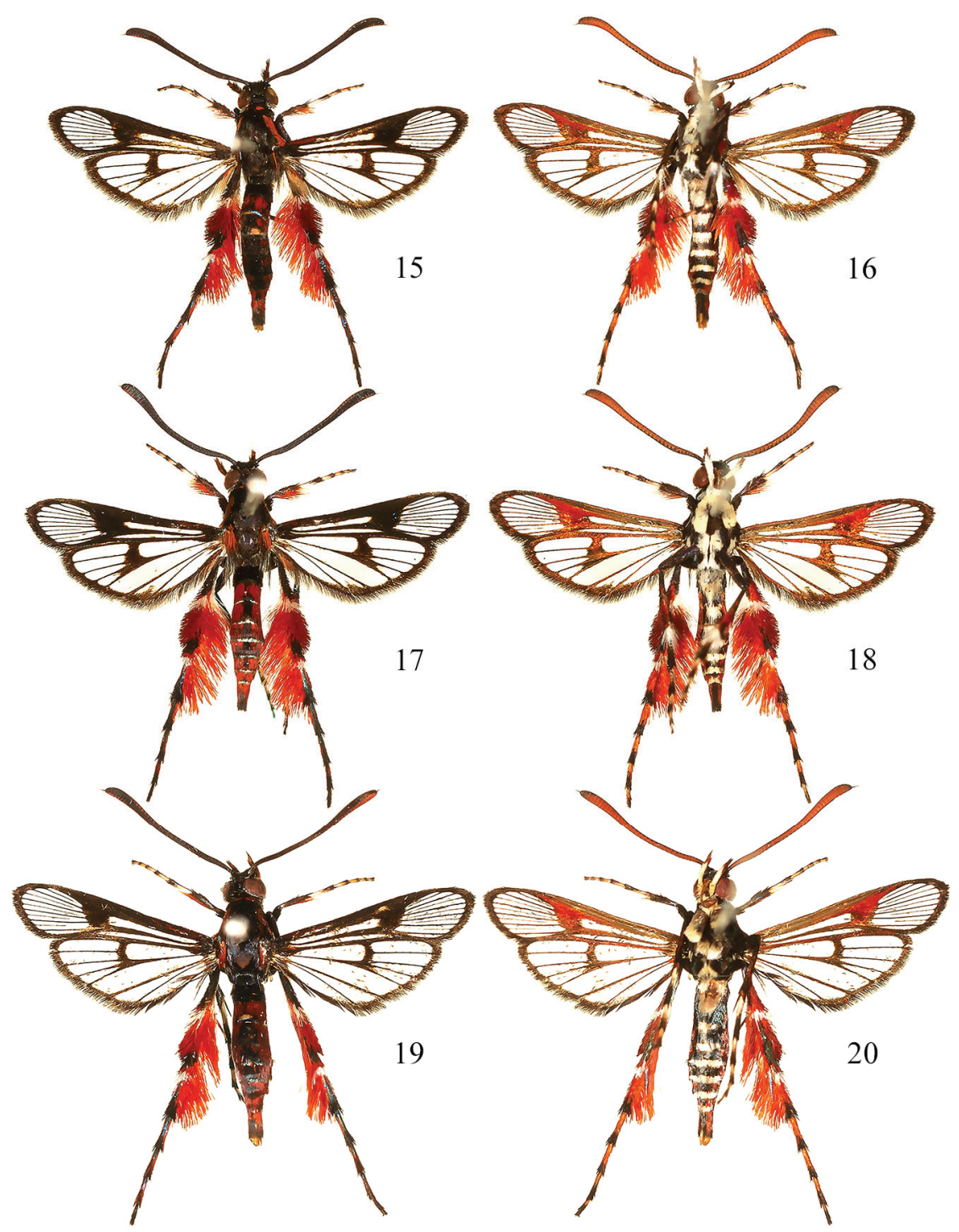

Figs 15-20. Variability of males of Nepyrophleps haematochrodes (Le Cerf, 1912), comb. n. 15 - upside. Laos, Khammouang Province, Ban Khounkham (Nahin), $18^{\circ} 13^{\prime} \mathrm{N}$, $104^{\circ} 31^{\prime}$ E, 200 m, 27.IV.2005, O. Gorbunov leg. Sesiidae picture No 0161-2021. Alar expanse $14.0 \mathrm{~mm} ; 16$ - ditto underside. Sesiidae picture No 0162-2021; 17 - upside. Laos, Khammouang Province, Ban Khounkham (Nahin), $18^{\circ} 13^{\prime} \mathrm{N}, 104^{\circ} 31^{\prime} \mathrm{E}, 200 \mathrm{~m}, 27 . \mathrm{IV} .2005$, O. Gorbunov leg. Sesiidae picture No 0165-2021. Alar expanse $14.7 \mathrm{~mm} ; 18$ - ditto underside. Sesiidae picture No 0166-2021; 19 - upside. Laos, Khammouang Province, Ban Khounkham (Nahin), $18^{\circ} 13^{\prime} \mathrm{N}, 104^{\circ} 31^{\prime} \mathrm{E}, 200 \mathrm{~m}, 25 . \mathrm{IV} .2005$, O. Gorbunov leg. Sesiidae picture No 0173-2021. Alar expanse 15.4 mm; 20 - ditto underside. Sesiidae picture No 0174-2021. 
rather sharply towards the apex, making distal half spear-shaped, at margins broadly covered with short and very thin hair-like setae at margins, with a raw of long and strong setae at sacculus; saccus short but broad, about as long as vinculum, straight basally; aedeagus relatively long, about 1.5 times as long as valva; vesica with numerous, minute, granular cornuti.

Female. Unknown.

DIFFERENTIAL DIAGNOSIS. Superficially, the species of this new genus are similar to representatives of the genus Aschistophleps Hampson, 1893, but can be easily distinguished from them by the structure of the hind leg tuft (tibia entirely tufted and basal tarsomere with a tuft of long hair-like scales in Aschistophleps, vs. only distal half of tibia and basal tarsomere tufted with long hair-like scales; compare Fig. 7 and Fig. 8), presence of brick-red scales on the thorax, legs, wings ventrally and abdomen, and by the structure of the male genitalia, especially shape of the gnathos and valva (compare Fig. 21 with fig. 14 in Gorbunov \& Arita, 1995 or fig. 14 in Arita \& Gorbunov, 2000). From Pyrophleps this new genus differs by the structure of the labial palpus (longer, tufted with long hair-like scales on mid joint in the genus compared; Figs 1, 2 vs. Fig. 4), shape of the eyes (distinctly bean-shaped eyes in Pyrophleps; Figs 1, 2 vs. Fig. 4), presence of brick-red scales on the thorax, wings ventrally and abdomen, and by the conformation of the valva in male genitalia (without a raw of long and strong setae at sacculus in Pyrophleps; Fig. 21 vs. figs 15 and 16 in Arita \& Gorbunov, 2000 or fig. 2 in Xu et al., 2015). From other genera of the tribe Osminiini, Nepyrophleps gen. $\mathrm{n}$. is clearly separable by the shape of the hind leg tuft and conformation of the male genitalia.

LIFE HISTORY. Nothing is known about the host plants and the biology of the preimaginal stages of all species of this new genus. All known specimens of the type species, except the holotype, were found among bees and wasps on wet soil on the bank of a small river.

COMPOSITION. I currently include only three species in this genus, namely $N$. haematochrodes (Le Cerf, 1912), comb. n., N. cucphuonganae (Arita et O. Gorbunov, 2000), comb. n., and N. bicella (Xu et Arita, 2015), comb. n. However, I have a suspicion that $N$. bicella is a junior synonym for $N$. cucphuonganae, but, unfortunately, at the present time I am not able to propose a synonymization formally due to lack of material of these two taxa.

DISTRIBUTION. Oriental Region: Laos, South China and North Vietnam.

ETYMOLOGY. The name of this new genus comes from the closely related genus Pyrophleps and from the Russian negative particle "He [ne]" (= not), denoting the negation of what is indicated by the word to which it refers in meaning. The gender is feminine.

Nepyrophleps haematochrodes (Le Cerf, 1912), comb. n. Figs 4, 8-21

Aschistophleps haematochrodes Le Cerf, 1912: 54, fig. 1 [Holotype $\widehat{\delta}$ (not $ᄋ$ !), “Tonkin: SuYut, sur la rivière Noire, VII. 1911" (= Vietnam: Hòa Bình Province, somewhere on the banks of the Song Da River); deposition unknown but not in Muséum national d'histoire naturelle, Paris, France]. 
Aschistophleps haematochrodes: Gorbunov \& Arita, 1995: 83; Skowron Volponi \& Volponi, 2017: 129; Kallies \& Štolc, 2018: 597; Pühringer \& Kallies, 2021.

Heterosphecia haematochrodes: Hampson, 1919: 53; Dalla Torre \& Strand, 1925: 4; Gaede, 1933: 778; Heppner \& Duckworth, 1981: 43.

Pyrophleps haematochrodes: Arita \& Gorbunov, 2000: 65, 67, 70, 72; Pühringer \& Kallies 2004: 14; Xu et al., 2015: 149, 151; Skowron Volponi \& Volponi, 2017: 134, 137.

MATERIAL. Totally 67 $\widehat{\partial}$ (Figs 9-20). Laos: Khammouang Province, Ban Khounkham (Nahin), 18 $13^{\prime} \mathrm{N}, 104^{\circ} 31^{\prime} \mathrm{E}, 200 \mathrm{~m}, 01-02 . \mathrm{V}$ 2002, 1 ô, V. Tuzov leg.; same locality, 16.IV 2005, $5 \hat{\jmath} \hat{\jmath}$, O. Gorbunov leg.; same locality, 17.IV 2005, 1 §., O. Gorbunov leg. (Sesiidae pictures No 0839-0840-2014); same locality, 18.IV 2005, $2 \hat{\jmath} \hat{\jmath}$, O. Gorbunov leg. (Sesiidae pictures No 0841-0842-

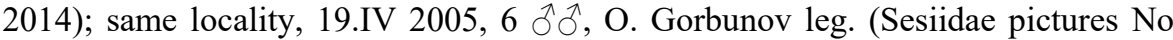

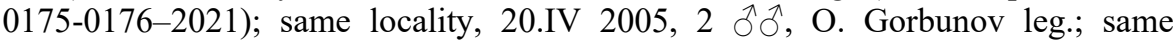
locality, 22.IV 2005, $2 \partial^{\lambda}$, O. Gorbunov leg.; same locality, 23.IV 2005, $1 \hat{\partial}$, O. Gorbunov leg.; same locality, 24.IV 2005, 8 $\hat{\jmath}$, O. Gorbunov leg. (genitalia

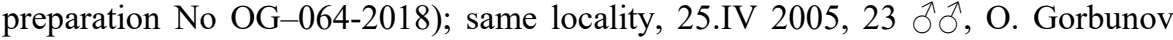
leg. (Sesiidae pictures No 0169-0174-2021); same locality, 26.IV 2005, $1 \hat{\jmath}$, O. Gorbunov leg.; same locality, 27.IV 2005, $8 \hat{\jmath} \hat{\jmath}$, O. Gorbunov leg. (Sesiidae pictures No 0161-0168-2021); same locality, 28.IV 2005, 7 ふぇ, O. Gorbunov leg. (Sesiidae pictures No 0151-0160-2021).

REDESCRIPTION. Male (Figs 9, 10). Alar expanse $14.4 \mathrm{~mm}$; body length 8.8 $\mathrm{mm}$; forewing $6.6 \mathrm{~mm}$; antenna $4.6 \mathrm{~mm}$.

Head with antenna dorsally black dark violet tint, ventrally ochreous but densely covered with thin orange scales with golden sheen masking background colouration; scapus black with dark violet sheen; frons dark brown to black with bright greenishviolet sheen; labial palpus white in basal half and brick-red mixed with black in distal half; vertex black with greenish-bronze sheen; occipital fringe laterally white, dorsally mixed with black and brick-red hair-like scales.

Thorax with patagia black with greenish-violet sheen and a few orange scales anteriorly; tegula black with dark violet sheen densely covered with dark orange scales masking background colouration; meso- and methorax black with dark greenish-violet sheen and a tuft of white hair-like scales on metathorax laterally; thorax laterally dark grey-brown with greenish-violet sheen and a narrow white stripe at distal margin of mesomeron; posteriorly both metepimeron and metameron dark grey-brown with greenish sheen densely covered with white hair-like scales. Legs with neck plate white with golden hue; fore coxa white with golden hue and a short and narrow black stripe with bronze-violet sheen externally at base; fore femur black with dark violet sheen; fore tibia black with bright violet sheen and a tuft of brick-red elongated scales at posterior margin; fore basal tarsomere dorsally black with blue-violet sheen, ventrally white with a few yellowish scales with golden hue distally, remaining tarsomeres dorsally black with violet sheen and a few pale orange scales basally, ventrally yellowish with golden hue; mid coxa white with golden hue; mid femur black with blue-violet sheen; mid tibia black with dark blueviolet sheen and with a spot of elongated brick-red scales exterior-medially; spurs externally dark brown with bronze-violet sheen, internally white; basal mid tarsomere 
dark brown to black with purple sheen, a broad white ring basally and a tuft of elongated white scales interior-basally; remaining tarsomeres dark brown to black with dark purple sheen, with a narrow pale orange to pale yellow ring basally and with a few pale yellow scales with electric-blue sheen dorso-basally; hind coxa white with golden hue; hind femur black with blue-violet sheen; hind tibia in basal half dark brown to black with greenish-purple sheen, proximal half brick-red with a narrow white ring at base of mid spurs, with a small black spot with dark purple sheen dorsodistally and with a small spot of black scales with strong electric greenish-blue sheen exterior-distally; both interior spurs dark brown with bronze-violet sheen, exterior ones white; hind tarsus brick-red, dorsally narrowly black with dark greenish-purple sheen, distally on each tarsomere narrowly ringed with black dark greenish-purple sheen, and with a narrow white ring basally on basal tarsomere. Forewing dorsally costal and anal margins, CuA-stem, discal spot, veins within external transparent area and apical area dark brown to black with dark purple sheen; basally with two groups of individual brick-red scales both at costal and anal margins; discal spot broad; ventrally costal and margins and $\mathrm{CuA}$-stem ochreous with an admixture of brick-red scales distally; discal spot and surface between veins $\mathrm{R}_{1}-\mathrm{R}_{3+4}$ brick-red with a few dark brown scales with bronze sheen on discal spot basally; veins within external transparent area and apical area dark brown to black with bronze-violet sheen; transparent areas well-developed, anterior transparent area large; posterior transparent area reaching the middle of discal spot; external transparent area extremely large, divided into six cells between veins $\mathrm{R}_{3+4}-\mathrm{CuA}_{2}$, cells between veins $\mathrm{R}_{3+4}-\mathrm{CuA}_{1}$ divided by a scaled stripe running from apical area through most of the cell; apical area narrow, about as broad as cilia; cilia dark brown to black with dark purple sheen. Hindwing transparent; dorsally veins, discal spot and outer margin dark brown to black with dark purple sheen; ventrally veins, discal spot and outer margin dark brown to black with bronze-violet sheen with an admixture of brick-red scales on costal margin, discal spot, veins $\mathrm{CuA}_{1}$ and $\mathrm{CuP}$, and outer margin anally; discal spot broad; surface between veins $\mathrm{CuA}_{1}$ and $\mathrm{CuA}_{2}$ opaque in basal half; outer margin narrow but with a distinct cuneiform projection between veins $\mathrm{CuP}$ and $1 \mathrm{~A}$; cilia dark brown to black with dark purple sheen.

Abdomen dorsally black with dark purple sheen; tergites 2-7 each densely covered with brick-red scales masking background colouration; distal row of scales on tergites 2-7 with a strong silvery hue; ventrally sternite $1+2$ white with golden hue; remaining sternites dark brown to black with dark bronze sheen and a broad white stripe with golden hue distally; anal tuft nearly undeveloped.

Male genitalia (genital preparation No OG-064-2018) (Figs 21, 22). Tegumenuncus complex narrow laterally, but broad ventrally; uncus with a semi-oval plate of long hair-like setae lateral-apically, covering tuba analis like a collar; gnathos narrow, long, distinctly protruding caudally; valva gradually widens towards the center, and then narrows rather sharply towards the apex, making distal half spearshaped, at margins broadly covered with short and very thin hair-like setae at margins, with a sparse raw of long, strong but light setae at sacculus; saccus short but broad, about as long as vinculum, straight basally; aedeagus relatively long, about 1.5 times as long as valva; vesica with numerous, minute, granular cornuti. 
Female. Unknown.

Individual variability (Figs 9-20). This species is nearly invariable in details of the coloration of various parts of the body, but old and not so fresh specimens are darker because missing the brightly coloured scales. Transparent areas of the forewing are practically invariable, but slightly varying the number of scales between veins $\mathrm{CuA}_{1}$ and $\mathrm{CuA}_{2}$ basally and $\mathrm{CuP}$ and $1 \mathrm{~A}$ distally on hindwing. However, it is rather variable in individual size: alar expanse $10.2-16.0 \mathrm{~mm}$; body length $5.3-8.9$ $\mathrm{mm}$; forewing 4.2-7.1 mm; antenna 3.1-4.9 $\mathrm{mm}$.

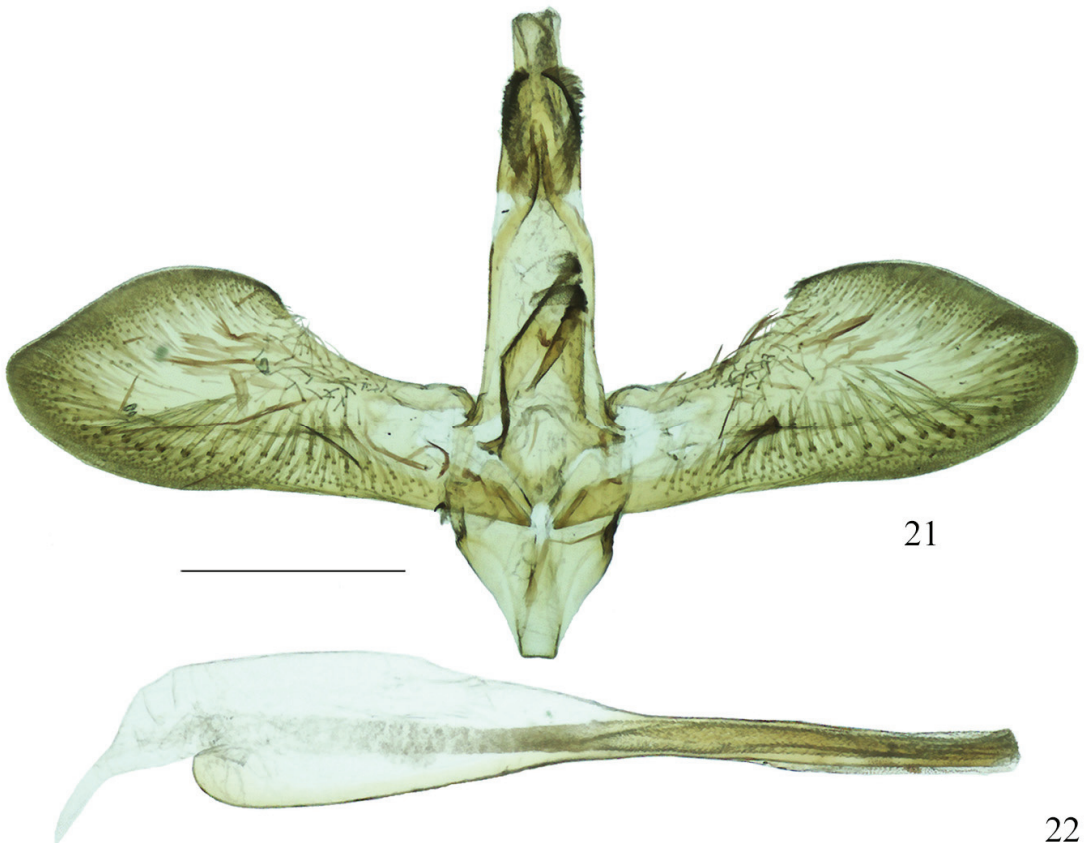

Figs 21-22. Male genitalia of Nepyrophleps haematochrodes (Le Cerf, 1912), comb. n. 21 - ventral view; 22 - aedeagus. Scale bar $05 . \mathrm{mm}$.

DIFFERENTIAL DIAGNOSES. This species is clearly distinguishable from $N$. cucphuonganae and $N$. bicella by more developed anterior and posterior transparent areas of the forewing and by the almost completely transparent hindwing (compare Figs 9-20 with fig. 6 in Arita, Gorbunov, 2000, fig. 1 in Xu et al., 2015 and fig. 2 in Kallies \& Štolc, 2018). The genitalia of these species are practically non-diagnostic (compare Figs 21, 22 and fig. 17 in Arita, Gorbunov, 2000 and fig. 2 in Xu et al., 2015).

BIONOMICS. The larval host plant and its biology are unknown. The specimens were collected in April, early May and July (the holotype). All specimens from Laos were found among wasps and bees on wet soil near the drying Nam Sanam stream. All of them were collected by a butterfly net. 
HABITAT. In Laos, this species inhabits a primary, monsoon, semi-deciduous, lowland, tropical forest with Dipterocarpus alatus Roxb. ex G.Don, Hopea odorata Roxb., H. ferrea Laness. (Dipterocarpaceae), Lagerstroemia cochinchinensis Pierre ex Laness. (Lythraceae), Afzelia xylocarpa (Kurz) Craib (Fabaceae) and Alstonia scholaris (L.) R. Br. (Apocynaceae) as the most dominant species.

DISTRIBUTION. This species is known to occur only from Laos (Khammouang Province) (this is the first record for the country) and North Vietnam (Hòa Bình Province).

\section{ACKNOWLEDGEMENTS}

I would like to express my cordial thanks to Mr. Alexey N. Zamesov (Moscow, Russia) for the company and help during our successful trip to Laos in 2005, Dr. Marta A. Skowron Volponi (Warsaw, Poland) for a very productive discussion about Oriental Osminiini, Dr. Vasily K. Tuzov (Moscow, Russia) for the gift of material, and Mr. Vlad Proklov (London, England) for carefully checking the English of an advanced draft.

The study was conducted using the equipment of the Joint Usage Center "Instrumental methods in ecology" at the A.N. Severtsov Institute of Ecology and Evolution, Russian Academy of Sciences (Moscow, Russia).

\section{REFERENCES}

Arita, Y. \& Gorbunov, O.G. 2000. Notes on the tribe Osminiini (Lepidoptera, Sesiidae) from Vietnam, with descriptions of new taxa. Transactions of the Lepidopterological Society of Japan, 51(1): 49-74.

Dalla Torre, K.W. \& Strand, E. von 1925. Aegeriidae. In: Strand, E. (Hrsg.). Lepidopterorum Catalogus, 31. W. Junk, Berlin. 202 pp.

Gaede, M. 1933. 23. Familie: Aegeriidae. P. 775-802, Taf. 94-95. In: Seitz, A. (Hrsg.) 1926-1930. Die Gross-Schmetterlinge der Erde, 10 (Die indoaustralischen Spinner und Schwärmer). A. Kernen Verlag, Stuttgart.

Gorbunov, O.G., 2015. Clearwing moths (Lepidoptera: Sesiidae) of Laos. I. Akaisphecia melanopuncta O. Gorbunov \& Arita, 1995 (Sesiidae: Sesiinae: Osminiini). Tropical Lepidoptera Research, 25(2): 98-100.

Gorbunov, O.G. \& Arita, Y. 1995. New and poorly known clearwing moth taxa from Vietnam (Lepidoptera, Sesiidae). Transactions of the Lepidopterological Society of Japan, 46(2): 69-90.

Hampson, G.F. 1919. A classification of the Aegeriadae [sic] of the Oriental and Ethiopian Regions. Novitates Zoologicae, 26(1): 46-119. DOI: https://doi.org/105962/bhl.part.5633

Heppner, J.B. \& Duckworth, W.D. 1981. Classification of the Superfamily Sesioidea (Lepidoptera, Ditrysia). Smithsonian Contribution to Zoology, 314: 1-144.

Kallies, A. \& Štolc, V. 2018. A new species of Aschistophleps from Thailand and Laos, with a new generic synonymy (Lepidoptera, Sesiidae). Zootaxa, 4446(4): 596-600. DOI: https://doi.org/10.11646/zootaxa.4446.4.11

Pühringer, F. \& Kallies, A. 2004. Provisional checklist of the Sesiidae of the world (Lepidoptera: Ditrysia). Mitteilungen der Entomologischen Arbeitsgemeinschaft Salzkammergut, 4: $1-85$. 
Pühringer, F. \& Kallies, A. 2021. Checklist of the Sesiidae of the world (Lepidoptera: Ditrysia). Online database. Last modified: 21.11.2020. Available from: http://www.sesiidae.net/ (accessed 01 April 2021)

Skowron Volponi, M.A. \& Volponi, P. 2017. A new species of wasp-mimicking clearwing moth from Peninsular Malaysia with DNA barcode and behavioural notes (Lepidoptera, Sesiidae). ZooKeys, 692: 129-139. DOI: https://doi.org/10.3897/zookeys.692.13587

The Plant List, 2013. Version 1.1. Available from: http://www.theplantlist.org/ (accessed 01 April 2021)

Xu, H.-M., Arita, Y., Chen, B. \& Wang, M. 2015. Description of Pyrophleps bicella (Lepidoptera: Sesiidae), a new Chinese species of clearwing moth. Florida Entomologist, 98 (1): 149-151. 